\title{
Article \\ Quercus suber Roots Activate Antioxidant and Membrane Protective Processes in Response to High Salinity
}

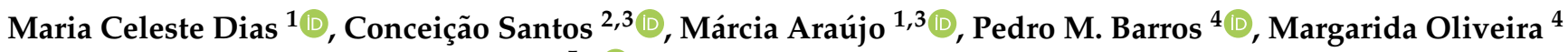 \\ and José Miguel P. Ferreira de Oliveira ${ }^{5, * \text { (D) }}$
}

check for

updates

Citation: Dias, M.C.; Santos, C.; Araújo, M.; Barros, P.M.; Oliveira, M.; de Oliveira, J.M.P.F. Quercus suber Roots Activate Antioxidant and Membrane Protective Processes in Response to High Salinity. Plants 2022, 11, 557. https://doi.org/ $10.3390 /$ plants 11040557

Academic Editor: Juan Barceló

Received: 17 January 2022

Accepted: 17 February 2022

Published: 19 February 2022

Publisher's Note: MDPI stays neutral with regard to jurisdictional claims in published maps and institutional affiliations.

Copyright: (C) 2022 by the authors. Licensee MDPI, Basel, Switzerland. This article is an open access article distributed under the terms and conditions of the Creative Commons Attribution (CC BY) license (https:// creativecommons.org/licenses/by/ $4.0 /)$.
1 Centre for Functional Ecology, Department of Life Sciences, University of Coimbra, Calçada Martim de Freitas, 3000-456 Coimbra, Portugal; celeste.dias@uc.pt (M.C.D.); marciaaraujo@fc.up.pt (M.A.)

2 LAQV, REQUIMTE, Faculty of Sciences, University of Porto, Rua do Campo Alegre, 4169-007 Porto, Portugal; csantos@fc.up.pt

3 IB2 Laboratory, Department of Biology, Faculty of Sciences, University of Porto, Rua do Campo Alegre, 4169-007 Porto, Portugal

4 Instituto de Tecnologia Química e Biológica António Xavier, Universidade Nova de Lisboa, Genomics of Plant Stress, Av. da República, 2780-157 Oeiras, Portugal; pbarros@itqb.unl.pt (P.M.B.); mmolive@itqb.unl.pt (M.O.)

5 LAQV, REQUIMTE, Laboratory of Applied Chemistry, Department of Chemical Sciences, Faculty of Pharmacy, University of Porto, 4050-313 Porto, Portugal

* Correspondence: jmoliveira@ff.up.pt

\begin{abstract}
Cork oak (Quercus suber) is a species native to Mediterranean areas and its adaptation to the increasingly prevalent abiotic stresses, such as soil salinization, remain unknown. In sequence with recent studies on salt stress response in the leaf, it is fundamental to uncover the plasticity of roots directly exposed to high salinity to better understand how $Q$. suber copes with salt stress. In the present study we aimed to unveil the antioxidants and key-genes involved in the stress-responses (early vs. later responses) of $Q$. suber roots exposed to high salinity. Two-month-old $Q$. suber plants were watered with $300 \mathrm{mM} \mathrm{NaCl}$ solution and enzymatic and non-enzymatic antioxidants, lipid peroxidation and the relative expression of genes related to stress response were analysed $8 \mathrm{~h}$ and 6 days after salt treatment. After an $8 \mathrm{~h}$ of exposure, roots activated the expression of QsLTI30 and QsFAD7 genes involved in stress membrane protection, and QsRAV1 and QsCZF1 genes involved in tolerance and adaptation. As a result of the continued salinity stress (6 days), lipid peroxidation increased, which was associated with an upregulation of QsLTI30 gene. Moreover, other protective mechanisms were activated, such as the upregulation of genes related to antioxidant status, QsCSD1 and $Q s A P X 2$, and the increase of the antioxidant enzyme activities of superoxide dismutase, catalase, and ascorbate peroxidase, concomitantly with total antioxidant activity and phenols. These data suggest a response dependent on the time of salinity exposure, leading $Q$. suber roots to adopt protective complementary strategies to deal with salt stress.
\end{abstract}

Keywords: salinization; oxidative stress; membrane protection; AP2/ERF family transcription factors; zinc finger $\mathrm{CCCH}$ domain-containing proteins; dehydrins

\section{Introduction}

Soil salinization is a natural and anthropic process that is increasing in the western Mediterranean areas, mostly due to the ecological conditions of this region [1]. In particular, the increasing use of irrigation practices in agricultural lands with poor drainage and high evapotranspiration conditions have also contributed to salt accumulation and acceleration of land degradation in semiarid Mediterranean regions [1]. Therefore, soil salinity is considered an ongoing threat to plant growth in this region and may threaten the native forest ecosystems [2].

Soil salinity is a major abiotic factor contributing to decreased plant productivity and growth, and its occurrence leads to early signalling events, induction of a quiescent phase, 
and a recovery phase as a result of acclimation responses [3]. Salt stress can induce oxidative stress due to the excessive production of reactive oxygen species (ROS), such as $\mathrm{O}_{2}-{ }^{-}, \mathrm{H}_{2} \mathrm{O}_{2}$, and $\mathrm{OH}$ [4]. These ROS can damage lipids, proteins, and DNA, resulting for instance, in membrane damages and enzyme activity inhibition [4]. However, at lower levels, ROS also act as signalling molecules mediating salt tolerance [5]. ROS homeostasis during salinity stress is organelle-dependent and relies on the regulation of non-enzymatic (e.g., polyphenols, glutathione, and ascorbate) and enzymatic (e.g., superoxide dismutase, catalase, and ascorbate peroxidase) antioxidant levels, together with metabolic adaptations $[5,6]$.

The cellular and molecular mechanisms involved in adaptation to salinity is starting to be unveiled in model tree species, such as Populus and crops [6-9]. Several studies support an increase of transcripts associated to antioxidant enzymes in response to abiotic stress [3], namely CSD1 and MSD1 (coding for cytosolic and mitochondrial superoxide dismutase), and CAT2 and APX2 coding, respectively, for catalase and ascorbate peroxidase proteins, however, the stress response remains unclear in cork oak. Several transcription factors (TFs) were also found to be involved in abiotic stress responses. For instance, APETALA2/Ethylene-responsive factor (e.g., RAV1 and ERF1) and zinc finger CCCH domain-containing proteins (e.g., CZF1) are induced by saline stress increasing plant tolerance and adaptation [9-13]. Besides TFs, other proteins encoded by stress-responsive genes, such as dehydrins (e.g., LTI30), play a pivotal role in plant defence interacting with membranes phospholipids, proteins, and DNA, thereby protecting them from damage. In addition, fatty acid desaturases (e.g., FAD7) play a role in membrane fluidity [14]. The response of these membrane protective proteins to salt stress remains to be unveiled in cork oak. In a previous work developed by our team in $Q$. suber, several genes were identified as key-stress responsive genes [15]. According to these previous data, we selected the genes QsCZF1, QsERF5, QsFAD7, QsLTI30, and QsRAV1 for the present study, in order to quantify their role in the root's response/adaptation to salt stress.

Cork oak (Quercus suber L.) is a xerophytic forest species native to western Mediterranean forest ecosystems and is well adapted to the harsh environmental condition of this region, presenting a good tolerance to hot and dry environments and to low fertility soils [15]. Despite its relevant ecological and economic importance, cork oak has been declining in native areas mostly due to inappropriate land-use policies and extreme weather climate change events that have been frequent in the Mediterranean region [16]. To tackle this potential threat, genomic studies as well as transcriptomic analysis in multiple tissues, developmental stages, and physiological conditions have been developed, mostly related to heat and drought [16-19]. In this respect, Pereira-Leal et al. [16] identified several expressed sequence tags over-represented in a cDNA library from $Q$. suber roots and shoots under drought, salt, and oxidative stress conditions. Despite the results of this study, the response to salinity in $Q$. suber, particularly at the gene expression level, remains unclear. Most of the studies on salt stress tolerance and adaptation mechanism were performed with other economically important tree species, e.g., pine and eucalyptus [20-22]. These studies showed a high tolerance to $\mathrm{NaCl}$ concentrations closer to $200 \mathrm{mM}$ in irrigation water. Other works conducted in important crop species, e.g., soybean, rice, and wheat, explored higher salt concentrations, $300 \mathrm{mM}$, and despite some sensitivity these works provide important information for further breeding programs or genetic manipulation [23-25].

We have recently demonstrated [26] that leaves of young cork oak plants exposed to $300 \mathrm{mM} \mathrm{NaCl}$ showed oxidative damages, photosynthetic impairment, and chlorophyll decreases. However, in the same study, cork oak leaves also showed features of salt-tolerant species, such as increased energy dissipation mechanisms (non-photochemical quenching), accumulated primary metabolites (soluble sugars and starch), and upregulated antioxidant enzymes to cope with the salt stress. Considering that root surfaces are first exposed to soil salinity, the plasticity of this organ can be the key to cope with salinity. Taking in consideration the previous data of leaf responses to high salinity, we hypothesize that cork oak plants may exhibit tolerance to salt stress, by upregulating protective mechanisms, particularly in the roots. In this study we aim to unveil the protective strategies 
adopted by Q. suber roots during salt stress. Q. suber plants were exposed to a high salinity episode $(300 \mathrm{mM} \mathrm{NaCl})$ and parameters related to oxidative damages, antioxidant system (enzymatic and non-enzymatic), as well as the expression of genes potentially related to saline stress protection and tolerance were analysed $8 \mathrm{~h}$ (early response) and 6 days (later response) after a salt application.

\section{Results}

\subsection{Oxidative Stress Status}

In order to elucidate the general status of oxidative stress in $\mathrm{Q}$. suber roots, the levels of malondialdehyde (MDA), a biomarker of lipid peroxidation, were measured. Additionally, the antioxidant responses developed to counteract these negative effects were analysed by quantifying the total antioxidant activity (TAA) and total phenols. Upon watering with $300 \mathrm{mM} \mathrm{NaCl}$, Q. suber roots showed differential responses in TAA, phenols content, and lipid peroxidation (Figure $1 \mathrm{~A}-\mathrm{C}$ respectively). TAA and lipid peroxidation were significantly decreased $8 \mathrm{~h}$ after exposure to salt compared to control. However, after 6 days, TAA and lipid peroxidation were significantly increased in salt-stressed roots (compared to control), with TAA increasing 25\% and MDA levels increasing $~ 23 \%$ $(p<0.05)$. Concerning total phenols content, although levels in roots were not found to be significantly different after $8 \mathrm{~h}$, they significantly increased $\sim 35 \%$ after 6 days of watering with $300 \mathrm{mM} \mathrm{NaCl}$ when compared to the control.

A)

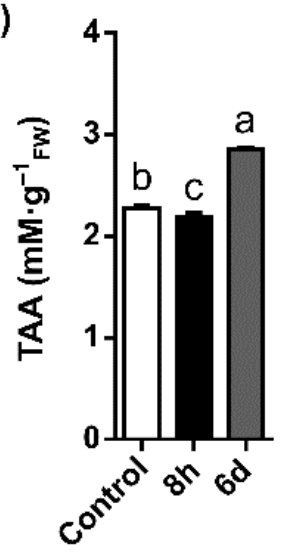

B)

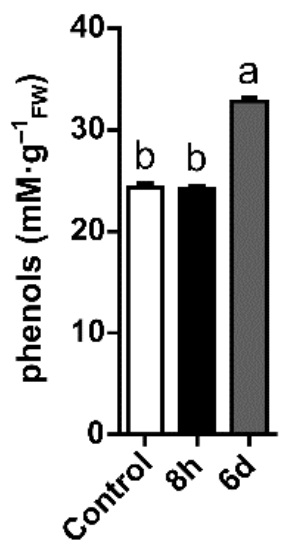

C)

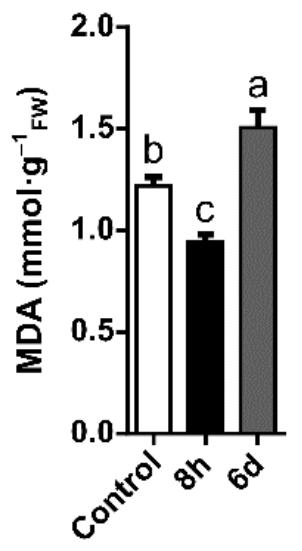

Figure 1. Root total antioxidant activity (A), total phenol content (B), and malondialdehyde level (C) in Q. suber roots under control and salinity conditions $(8 \mathrm{~h}$ and 6 days after $300 \mathrm{mM} \mathrm{NaCl}$ treatment). White bars: control; black bars: $8 \mathrm{~h}$; grey bars: 6 days. Values are mean $\pm \operatorname{SEM}(\mathrm{n}=6)$. Letters indicate significant differences between groups $(p<0.05)$.

\subsection{Antioxidant Enzyme-Encoding Genes and-Activities}

Following the assessment of oxidative stress status, Q. suber was probed for possible adaptations to the underlying oxidative stress originating from salinity. Herewith, the effect of salinity was determined on the gene expression and activity of superoxide dismutase (SOD), ascorbate peroxidase (APX), and catalase (CAT) antioxidant enzymes. The gene expression of the antioxidant enzymes was not significantly affected $8 \mathrm{~h}$ after the saline treatment (Figure 2A). However, after 6 days, relative expression was $\sim 4.5$-fold increased for QsCSD1 and 2.4-fold increased for QsAPX2, in NaCl treatment compared to the control. The activities of SOD, CAT, and APX are represented in Figure 2B. The activities of CAT and SOD in Q. suber roots increased significantly after $8 \mathrm{~h}$ and 6 days of $\mathrm{NaCl}$ treatment, when compared to the control. After $8 \mathrm{~h} \mathrm{NaCl}$ treatment, APX activity in Q. suber roots was not significantly different from the control. However, 6 days after $\mathrm{NaCl}$ treatment, APX activity was significantly higher than the control. 
A)

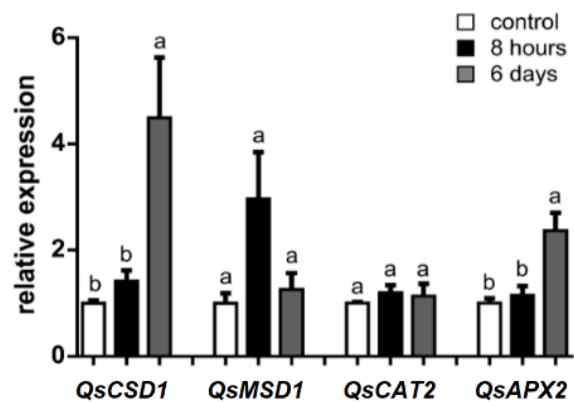

B)

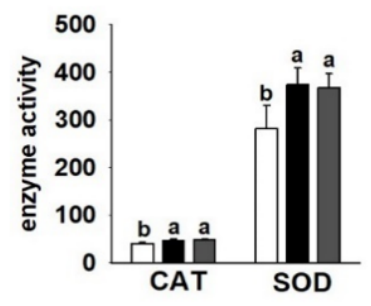

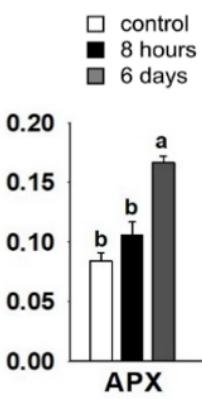

Figure 2. Relative expression levels of genes encoding antioxidant enzymes (A) and antioxidant enzyme activities (CAT—catalase, SOD—superoxide dismutase, and APX—ascorbate peroxidase) (B) in Q. suber roots under control and salinity conditions $(8 \mathrm{~h}$ and 6 days after $300 \mathrm{mM} \mathrm{NaCl}$ treatment). The target genes were: copper/zinc superoxide dismutase (QsCSD1), manganese superoxide dismutase (QsMSD1), catalase (QsCAT2), and ascorbate peroxidase 2 (QsAPX2). White bars: control; black bars: $8 \mathrm{~h}$; grey bars: 6 days. Values are mean $\pm \operatorname{SEM}(n=3-6)$. For each gene or enzyme different letters indicate significant differences between control and salinity treatments $(p<0.05)$.

\subsection{Relative Expression of Genes Related to Stress Response}

With the aim of investigating the role of putative stress-related genes, relative expression was determined for genes related to saline stress protection and tolerance, most notably QsCZF1, QsERF5, QsFAD7, QsLTI30, and QsRAV1. After $8 \mathrm{~h}$ of saline stress, relative expression increased for all genes, with significant upregulation observed for the transcription-factor encoding genes QsCZF1 and QsRAV1, and membrane protective genes QsLTI30 and QsFAD7, compared to the control (Figure 3). The largest increase in relative expression, $\sim 6.9$ fold, $8 \mathrm{~h}$ exposure vs. control, was observed for the QsLTI30 and the second largest increase, $\sim 4.9$ fold, $8 \mathrm{~h}$ exposure vs. control, was for the QsRAV1. Moreover, a significant increase in relative expression ( $8 \mathrm{~h}$ exposure) was found for QsFAD7 ( 3.7 fold) and for the QsCZF1 ( 1.9 fold). After 6 days, compared to $8 \mathrm{~h}$ exposure, a general decrease was observed in the expression of the selected genes, significant for the QsRAV1 and QsLTI30 genes.

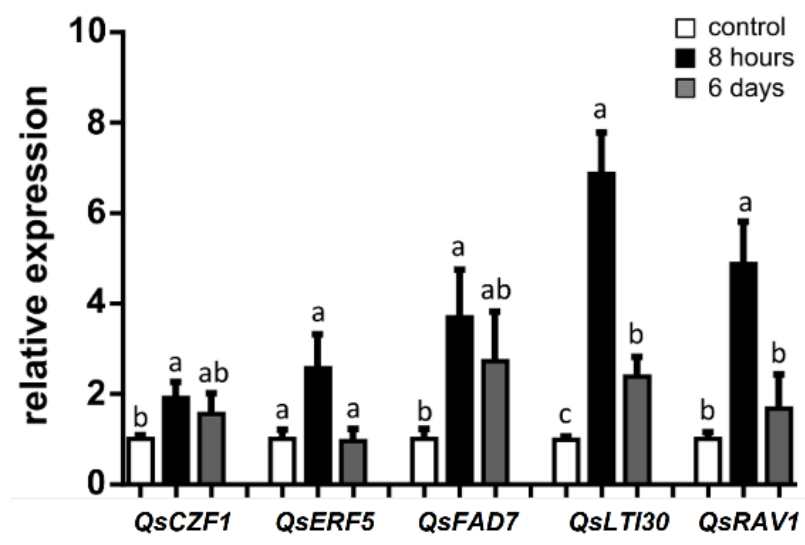

Figure 3. Relative expression levels of genes encoding stress biomarkers in $Q$. suber roots under control and salinity conditions ( $8 \mathrm{~h}$ and 6 days after $300 \mathrm{mM} \mathrm{NaCl}$ treatment). Values are mean $\pm \mathrm{SEM}$ $(n=6)$. For each gene, different letters indicate significant differences between control and salinity treatments $(p<0.05)$.

\subsection{Correlations and Principal Component Analysis}

The above-described quantitative data was analysed by Pearson correlation and principal component analysis (PCA) with the goal of identifying trends of variation. Concerning oxidative stress related genes, under the experimental conditions tested, there was a significant positive correlation between QsCSD1 and QsAPX2 gene expression (correlation index $1.0, p<0.01$ ), as shown (Figure 4A). 
A)

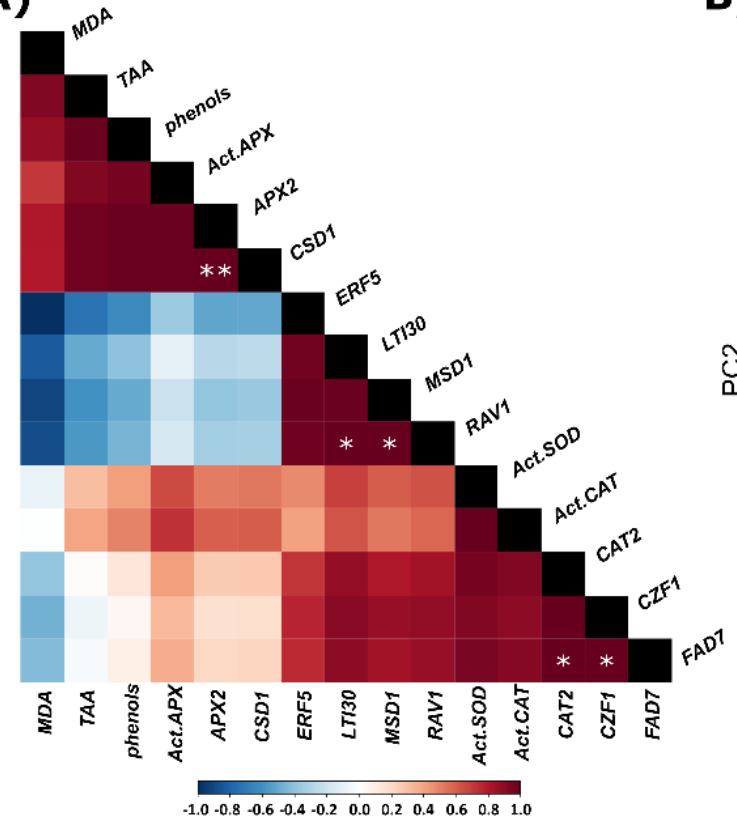

B)

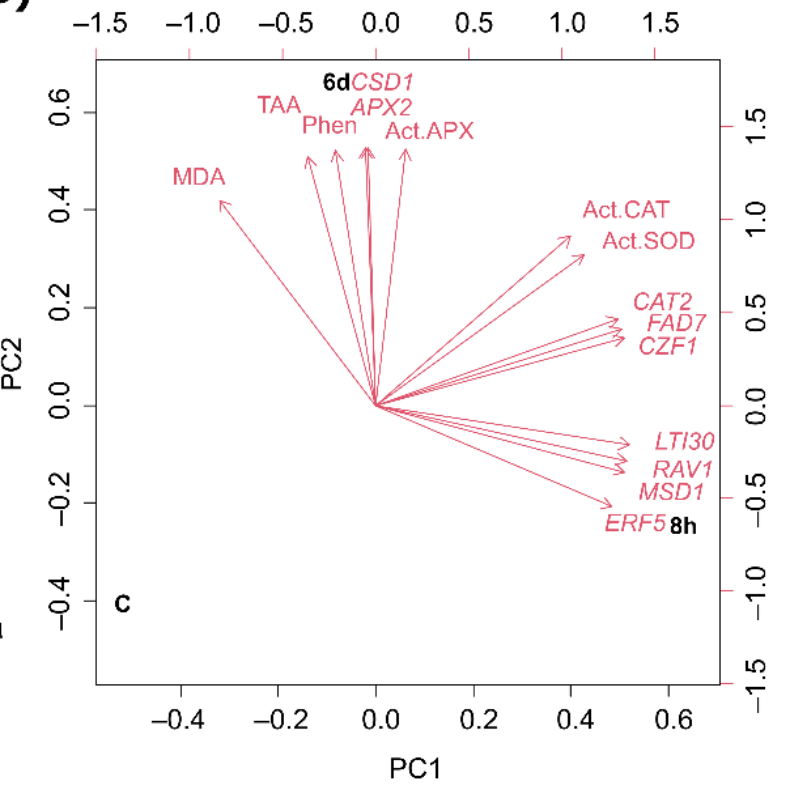

Figure 4. Correlation and PCA of the data. (A) Pearson correlation coefficients indicate negative (blue) or positive (red) correlations. ${ }^{*} p<0.05$; ${ }^{* *} p<0.01$; (B) PCA biplot of the data in $Q$. suber. $\mathrm{C}$-control, $8 \mathrm{~h}-8 \mathrm{~h}$ after $\mathrm{NaCl}$ treatment, and $6 \mathrm{~d}-6$ days after $\mathrm{NaCl}$ treatment.

Regarding hypothetical stress-related genes, the genes investigated which were significantly upregulated in saline conditions showed significant positive correlations, viz. QsLTI30 gene together with QsRAV1 (correlation index 1.0, $p<0.05$ ), and QsCZF1 gene together with QsFAD7 (correlation index 1.0, $p<0.05$ ). The only cluster observed consisted of dehydrin QsLTI30 and the two TF genes QsRAV1 and QsERF5.

PCA was performed to identify parameters associated with saline stress in $Q$. suber (Figure 4B). Three well-defined groups represent each condition (C, $8 \mathrm{~h}$ and 6 days). The parameters under research were associated with $8 \mathrm{~h}$ or 6 days saline stress, but not with the control condition. The parameters associated with early response to saline stress were the expression of the candidate stress-related genes QsERF5, QsRAV1, and QsLTI30, as well as the expression of mitochondrially-encoded superoxide dismutase QsMSD1. The parameters both associated with early and late response to saline stress were the expression of the candidate stress-related genes QsCZF1, QsFAD7, and QsCAT2, together with SOD and CAT enzyme activities. The parameters associated with response to late saline stress included the expression of QsCSD1 and QsAPX2 genes, APX enzyme activity, lipid peroxidation (measured in MDA equivalents), TAA, and phenols.

\section{Discussion}

Soil salinity is a growing threat to agroforest ecosystems in the Mediterranean, and its effects in forest species is far less known than drought stress, even in xerophytic species such as cork oak. Particularly intriguing is the identity of genes involved in regulating early vs. later responses. We demonstrated previously [26] that the application of $300 \mathrm{mM} \mathrm{NaCl}$ in young $Q$. suber plants induced leaf physiological responses as decrease of photosynthesis related parameters, pigments, and carbohydrate profiles. In addition, these studies showed antioxidant responses that were also dependent of the extent of salt exposure. Moreover, several leaf adaptation mechanisms to high salinity were also induced in Q. suber plants, suggesting a plastic adaptation of this species to cope with salinity. The roots are the first organ affected by soil salinity, therefore, to complement the previous studied in leaves [26], the present work focuses on this organ.

General oxidative status in the roots of $Q$. suber points to an initial adaptation to stress at $8 \mathrm{~h}$ exposure, as evidenced by a decrease in TAA and no change in phenol levels. A 
decrease in malondialdehyde levels from lipid peroxidation was also observed at this earlier time point. This observation after $8 \mathrm{~h}$, but not after 6 days of saline treatment, suggests that at $8 \mathrm{~h}$, the MDA decrease may not be a direct result of antioxidant enzymes battery, but rather result from other faster protective mechanisms, namely involving the membrane protection. We show that the most responsive protective mechanisms after $8 \mathrm{~h}$ can be related with synthesis of dehydrin, e.g., upregulation of QsLTI30 gene and membraneassociated proteins, e.g., upregulation of QsFAD7 gene. This enhanced synthesis can occur concomitantly with the increase in transcription factors such as CZF1 and RAV1, which regulate several defense genes. Interestingly, these effects were more evident after $8 \mathrm{~h}$ compared to a longer period of 6 days, the protective role of the antioxidant enzymes (e.g., SOD and APX) being more evident at this later time. An extensive crosstalk is frequently observed in the plant response against different types of abiotic stress. For example, in A. thaliana, LTI30 confers freeze-protection and this is due to its membrane interactions in stressed plants, and this characteristic is also crucial for the maintenance of cell membrane integrity during exposure to other types of abiotic stress such as osmotic or salinity stress $[27,28]$. Besides protection of membrane phospholipids and proteins, in various plant species dehydrins were reported to bind catalytic metal ions, thereby preventing the Fenton reaction [4] that produces the highly reactive hydroxyl radical. Additionally, in A. thaliana, there was an overexpression of AtLTI30 by drought stress and an increased activity of CAT, leading to a decrease of $\mathrm{H}_{2} \mathrm{O}_{2}$ levels and lower membrane oxidative damage [29]. Considering these previous observations, the large increase in QsLTI30 expression at $8 \mathrm{~h}$ exposure suggests that LTI30 protein may play a role in MDA decrease at this time point. The important protective role of LTI30 at this early period is also supported by the PCA (Figure 4). In addition to this response protection, an increase in SOD and CAT activities (together with the expression of mitochondrial Mn-SOD QsMSD1, albeit non-significant), suggests that a metabolic readjustment for detoxification of superoxide is initialized. Besides dehydrins stimulation, after $8 \mathrm{~h}$ there was an increase in the transcript levels of QsFAD7. The gene encoding FAD7 was reported to be upregulated in wound stressed A thaliana and Portulaca oleracea plants [30,31]. Additionally, in Gossypium hirsutum, a tissue-dependent GsFAD7 expression was observed, with reported increased expression in roots and decreased expression in leaves of plants exposed to salt stress conditions vs. control [32]. The overexpression of FAD7 in Nicotiana tabacum was also related with increased tolerance to cold stress, while antisense suppression of this gene enhanced plants' sensitivity to salt and drought stress [33]. The putative involvement of other transcription factors, in the early protective response $(8 \mathrm{~h})$ to salinity stress in $Q$. suber roots, is highlighted by the upregulation of QsCZF1 and QsRAV1 and suported by the PCA (Figure 4). The involvement of these genes in stress responses/tolerance was also reported for other species. In $A$. thaliana subjected to cold stress, CZF1 and RAV1 TFs were upregulated and also co-regulated [34]. Furthermore, in $Q$. suber roots $Q s R A V 1$ was previously found up-regulated but under drought conditions [35]. Overall, the important role of these stress genes at this early stage of salt stress $(8 \mathrm{~h})$ is reinforced by the multivariate analysis (Figure 4). Considering these previous observations, the increased expression of QsCZF1, and QsRAV1 could contribute to a specific adaptation of the cork oak roots to the early stages of salt stress.

With the extent of the salt stress ( 6 days after $\mathrm{NaCl}$ treatment) a higher antioxidant response was boosted by the $Q$. suber roots. This response includes an overexpression of QsCSD1 and QsAPX2, together with increased activities of SOD, APX, and CAT. In addition, both the pool of total phenol and the TAA increase after $6 \mathrm{~d}$ of $\mathrm{NaCl}$ treatment. The QsLTI30 gene, related to membrane and protein protection, which was overexpressed at the early stage of salt stress $(8 \mathrm{~h})$ remained highly expressed compared to the control at 6 days as well. However, these responses were not sufficient to completely prevent oxidative stress, since lipid peroxidation, a stress biomarker, increased at this stage. The increase of the involvement of enzymatic and non-enzymatic antioxidant battery at day 6 in response salt stress was also evidenced in the PCA (Figure 4). 
The role of antioxidant enzymes to deal with salt stress is reported in several studies. For instance, in the woody species, Broussonetia papyrifera, salt stress (150 $\mathrm{mM} \mathrm{NaCl}$ for 5 days) did not increase the levels of $\mathrm{H}_{2} \mathrm{O}_{2}$ in roots, possibly due to the action of the enzyme CAT [36]. Interestingly, in this species the SOD and peroxidase (POX) did not have an important role in stress protection. In the roots of Lycopersicon pennellii exposed to a lower $\mathrm{NaCl}$ dose (100 mM for 14 days), the upregulation of SOD, CAT, APX and monodehydroascorbate reductase (MDHA) was correlated with the reduction of oxidative stress biomarkers, lipid peroxidation, and $\mathrm{H}_{2} \mathrm{O}_{2}$ [37]. In addition, the increase in the activities and gene expression of SOD, CAT, APX, POX, and glutathione reductase (GR) in Hordeum vulgare roots five days after a treatment with $200 \mathrm{mM} \mathrm{NaCl}$ was correlated with $\mathrm{H}_{2} \mathrm{O}_{2}$ detoxification [38]. The accumulation of secondary metabolites, such as saponins and lignans that have antioxidant capacity, in Medicago sativa and Medicago arborea roots exposed to $100 \mathrm{mM} \mathrm{NaCl}$ for 10 days increased salt stress tolerance [39]. In Olea europaea, long exposure of roots to 75 and $100 \mathrm{mM} \mathrm{NaCl}$ induced the accumulation of polyphenols and the increase of TAA, which was related to protection against salinity stress [40].

\section{Materials and Methods}

\subsection{Reagents and Standards}

Ascorbic acid, sodium borate, disodium EDTA ( $\mathrm{Na}_{2}$ EDTA), dithiothreitol (DTT), ethylene glycol-bis(2-aminoethylether)- $\mathrm{N}, \mathrm{N}, \mathrm{N}^{\prime}, \mathrm{N}^{\prime}$-tetraacetic acid (EGTA), gallic acid, hydrogen peroxide, lithium chloride, methanol, methionine, nitro-blue tetrazolium chloride (NBT), polyvinylpyrrolidone (PVP), phenylmethylsulfonyl fluoride (PMSF), triton X-100, potassium sulphate, riboflavin, sodium carbonate, sodium chloride, sodium dodecyl sulfate (SDS), sulphuric acid, thiobarbituric acid (TBA), titanium dioxide, and trichloroacetic acid (TCA), Triton X-100 were purchased from Sigma-Aldrich (St. Louis, MO, USA).

\subsection{Plant Material and Experimental Design}

Q. suber half-sibling acorns (collected from one open pollinated mother tree growing at Instituto Superior de Agronomia in Lisbon, Portugal) were germinated in plastic dark pots $(400 \mathrm{~mL})$ with a soil mixture of turf and vermiculite (2:1) as described in Ferreira de Oliveira et al. [26]. Seedlings were grown in a climatic room with a photoperiod of $16 \mathrm{~h}$, a temperature of $22 \pm 2{ }^{\circ} \mathrm{C}$ and a photosynthetic photon flux density of $200 \pm 10 \mu \mathrm{mol} \mathrm{m}^{-2} \mathrm{~s}^{-1}$ for two months. After this period, two-month old plants were randomly divided into three groups: group (1) control-plants watered with $75 \mathrm{~mL}$ of water and samples collected after $8 \mathrm{~h}(\mathrm{n}=4)$ and 6 days $(\mathrm{n}=5)$; group (2) $8 \mathrm{~h}(8 \mathrm{~h})$ stress exposure-plants watered once with $75 \mathrm{~mL}$ of a solution of $300 \mathrm{mM} \mathrm{NaCl}$ and samples collected $8 \mathrm{~h}$ after this treatment $(\mathrm{n}=9)$; group (3) 6 days stress exposure-plants watered once with $75 \mathrm{~mL}$ of a solution of $300 \mathrm{mM} \mathrm{NaCl}$ and samples collected 6 days after this treatment $(n=9)$. At the end of the treatments, root samples were harvested, washed with ultra-pure water to remove the rest of the turf and vermiculite, immediately frozen in liquid nitrogen, and stored at $-80{ }^{\circ} \mathrm{C}$ for further determination of the relative expression of stress related genes, parameters related to the oxidative stress and antioxidant system.

\subsection{Total Antioxidant Activity (TAA) and Phenol}

Frozen root powder samples were mixed with methanol, sonicated $\left(40{ }^{\circ} \mathrm{C}, 30 \mathrm{~min}\right)$, and centrifuged $\left(15,000 \times g, 15 \mathrm{~min}, 4^{\circ} \mathrm{C}\right)$. The supernatant was used for TAA and phenols content determination. TAA was measured using the ABTS (2,20-azino-bis(3ethylbenzothiazoline-6-sulphonic acid)) scavenging assay [41]. ABTS solution was added to the extract and the absorbance was read at $734 \mathrm{~nm}$. The TAA was calculated from a gallic acid standard curve. The amount of phenols was quantified by incubating for 5 min the Folin-Ciocâlteu reagent with the supernatant and then adding $20 \% \mathrm{Na}_{2} \mathrm{CO}_{3}$. After $2.5 \mathrm{~h}$, the absorbance was read at $765 \mathrm{~nm}$ and a gallic acid standard curve was used to determine the phenols content. 


\subsection{Lipid Peroxidation}

Frozen root powder was used to assess lipid peroxidation by measuring the production of MDA [42]. Samples (100 mg) were mixed with $1.5 \mathrm{~mL}$ of $0.1 \%(w / v)$ TCA and centrifuged $\left(10,000 \times g, 10 \mathrm{~min}, 4^{\circ} \mathrm{C}\right)$. An aliquot per sample $(250 \mu \mathrm{L})$ was incubated at $95^{\circ} \mathrm{C}$ for $30 \mathrm{~min}$ with (a) $1 \mathrm{~mL}$ of $20 \%$ TCA $(w / v)$ and $0.5 \%$ TBA $(w / v)$ (+TBA, positive control) and, another (same sample); and with (b) $1 \mathrm{~mL}$ of $20 \%$ TCA $(w / v)$ (-TBA, negative control). Samples were immediately cooled on ice and centrifuged $\left(10,000 \times g, 10 \mathrm{~min}, 4^{\circ} \mathrm{C}\right)$. The absorbance was read at 440,532, and $600 \mathrm{~nm}$ using a Thermo Scientific spectrophotometer (Genesys 10-uv S) and the MDA equivalents were calculated according to Hodges et al. (1999) [42].

\subsection{RNA Extraction, Primer Design and $q P C R$}

Total RNA was extracted from roots following the Hot Borate method [43]. Total RNA was concentrated and purified (RNeasy MinElute Cleanup Kit, QIAGEN, Hilden, Germany). Before cDNA synthesis, total RNA samples were incubated with Turbo DNA-free (Turbo DNA-free Kit, Ambion, Life Technologies, Austin, TX, USA) to remove contaminating genomic DNA. Prior and after this treatment, total RNA was quantified on a Thermo Fisher Scientific spectrophotometer (NanoDrop 1000). After Turbo DNA-free treatment, $1 \mu \mathrm{g}$ total RNA was used to synthesize cDNA (Transcriptor High Fidelity cDNA, Roche, Switzerland) according to the manufacturer instructions. cDNA was diluted in ultrapure Milli-Q water (1:10). All qPCR reactions were performed using iTaq SYBR Green Supermix (BioRad, Hercules, CA, USA), $150 \mathrm{nM}$ each gene-specific primer, and $3 \mu \mathrm{L}$ pre-diluted cDNA in a final volume of $12 \mu \mathrm{L}$. The reactions were subjected to 1 cycle at $95{ }^{\circ} \mathrm{C}$ for $6 \mathrm{~s}$ and 60 cycles at $94{ }^{\circ} \mathrm{C}$ for $5 \mathrm{~s}, 58^{\circ} \mathrm{C}$ for $15 \mathrm{~s}$, and $72{ }^{\circ} \mathrm{C}$ for $15 \mathrm{~s}$ with fluorescence reading in the extension step. At least three qPCR technical replicates were performed per sample. A melting program was performed at the end of qPCR. Average PCR efficiency values and cycle thresholds (CTs) were estimated from the fluorescence data and used to calculate the relative gene expression [44]. Candidate stress-related genes were selected from the analysis of publicly available expression datasets obtained for cork oak tissues in response to abiotic (drought, heat and cold, salt) and biotic stress (P. cinnamomi infection). These datasets are available at www.corkoakdb.org (last accessed 1 March 2021). Gene-specific primers (Table 1) were designed using Primer 3 design tool [45] with published Quercus consensus sequences. Gene expression levels of target genes were calculated relative to control and double normalised with TUB2 (tubulin) and ACT7 (actin) reference genes according to the $\Delta \Delta C_{\mathrm{T}}$ method [45], after $\mathrm{C}_{\mathrm{T}}$ transformation with efficiency values.

\subsection{Antioxidant Enzyme Activities}

Root frozen samples powder were homogenized with an extraction buffer that contained 0.1 M potassium phosphate buffer $\mathrm{pH}$ 7.5, $0.5 \mathrm{mM} \mathrm{Na}_{2}$ EDTA, 0.2\% Triton X-100 $(v / v), 2 \mathrm{mM}$ DTT, $1 \mathrm{mM}$ PMSF, and 1\% PVP $(\mathrm{m} / v)$. After centrifugation $(12,000 \times g$ for $10 \mathrm{~min}$ at $4{ }^{\circ} \mathrm{C}$ ), the supernatant was used to measure the activities of the enzymes superoxide dismutase (SOD, EC1.15.1.1), ascorbate peroxidase (APX, EC 1.11.1.11), and catalase (CAT, EC 1.11.1.6). The activity of SOD was measured according to Agarwal et al. [46]. SOD activity was assessed at $25^{\circ} \mathrm{C}$ by following the reduction of the absorbance at 560 $\mathrm{nm}$ produced by the inhibition of the decrease of nitroblue tetrazolium chloride. The APX activity was determined using the protocol developed by Nakano and Asada [47]. $\mathrm{H}_{2} \mathrm{O}_{2}$ was used to start the reaction, and the reduction in the ascorbate was followed at $290 \mathrm{~nm}$. CAT activity was measured following the method of Beers and Sizer [48]. The decrease of absorbance at $240 \mathrm{~nm}$ at $25^{\circ} \mathrm{C}$ was followed after the addition of $20 \mathrm{mM} \mathrm{H}_{2} \mathrm{O}_{2}$.

\subsection{Data Analysis}

SigmaPlot for Windows version 3.1 was used to perform all statistical analysis. A t-test was performed to compare the control against each of the two experimental groups. Pearson's correlation was performed to evaluate the relationships between control and 
stress treatments among all parameters. PCA was performed with prcomp function of R software for Windows.

Table 1. Primers used for qPCR.

\begin{tabular}{|c|c|c|c|}
\hline Primers $\left(5^{\prime}-3^{\prime}\right)$ & $\begin{array}{l}\text { Target RNA Q. suber } \\
\text { (NCBI ID) }\end{array}$ & A. thaliana Gene/Locus & $\begin{array}{l}\text { Tblastx E-Value } \\
\text { (Coverage) }\end{array}$ \\
\hline $\begin{array}{l}\text { F_CTGAGCGGGAAATTGTTCGTG; } \\
\text { R_GCAGTCTCCAACTCCTGCTC }\end{array}$ & actin (XM_024037498.1) & ACT7 AT5G09810 & $0.0(70 \%)$ \\
\hline $\begin{array}{l}\text { F_TACTGTCCCAGAGCTCACCC; } \\
\text { R_CACGGAACATAGCTGAGGCA }\end{array}$ & tubulin (KJ563262.1) & TUB2 AT5G62690 & $0.0(96 \%)$ \\
\hline $\begin{array}{l}\text { F_CGCTCTTGGAGACACAACAA; } \\
\text { R_CCATCAGCACCAACATTGAC }\end{array}$ & $\begin{array}{l}\text { superoxide dismutase [Cu-Zn] } \\
\text { 4A (XM_024050079.1) }\end{array}$ & CSD1 AT1G08830 & $3 \times 10^{-87}(59 \%)$ \\
\hline $\begin{array}{c}\text { F_CCTTCTCTCTTCCCGATCTCTC; } \\
\text { R_GGAGTCGCCTTTAGCGATG }\end{array}$ & $\begin{array}{c}\text { superoxide dismutase [Mn] } \\
\text { (XM_024016741.1) }\end{array}$ & MSD1 AT3G10920 & $2 \times 10^{-124}(54 \%)$ \\
\hline $\begin{array}{l}\text { F_GCTAGGGGAGCTAGTGCAAAG; } \\
\text { R_CAGGGTTTCAGGGCTACCA }\end{array}$ & $\begin{array}{l}\text { catalase isozyme 3-like } \\
(\mathrm{XM} \text { 024064618.1) }\end{array}$ & CAT2 AT4G35090 & $0.0(81 \%)$ \\
\hline $\begin{array}{l}\text { F_CGGATCATCTGAGGGATGTATT; } \\
\text { R_CAAAAATAAGAGGGTTGCTGGTC }\end{array}$ & $\begin{array}{c}\text { L-ascorbate peroxidase, } \\
\text { cytosolic (XM_024061016.1) }\end{array}$ & APX2 AT3G09640 & $2 \times 10^{-138}(61 \%)$ \\
\hline $\begin{array}{l}\text { F_GCTCCTTGAGGCATCACACT; } \\
\text { R_AGGCGATGGAGTTGGTTCTG }\end{array}$ & $\begin{array}{c}\text { Zn finger CCCH } \\
\text { domain-containing protein } \\
\text { 29-like (XM_024044287.1) }\end{array}$ & CZF1 AT2G40140 & $0.0(58 \%)$ \\
\hline $\begin{array}{l}\text { F_GCCGTTATCTCCGCATCCTT; } \\
\text { R_CCACCAGCACCATTAGCAGA }\end{array}$ & $\begin{array}{c}\text { E-responsive TF ERF105-like } \\
\text { (XM_024066622.1) }\end{array}$ & ERF5 AT5G47230 & $4 \times 10^{-26}(24 \%)$ \\
\hline $\begin{array}{l}\text { F_GACCCACCTCATACAAGCCC; } \\
\text { R_TTAGCCCCCAGTTCCTGTCT }\end{array}$ & $\begin{array}{l}\text { omega-3 fatty acid desaturase } \\
\text { (XM_024037902.1) }\end{array}$ & FAD7 AT3G11170 & $2 \times 10^{-135}(38 \%)$ \\
\hline $\begin{array}{l}\text { F_ATATGGCAACCCAACCCACC; } \\
\text { R_CATACCTTGGAGAGTGGCGG }\end{array}$ & $\begin{array}{l}\text { dehydrin Xero 1-like } \\
\text { (XM_024052398.1) }\end{array}$ & LTI30/XERO2 AT3G50970 & $2 \times 10^{-13}(46 \%)$ \\
\hline $\begin{array}{l}\text { F_AAGCCGGTTCAACTTTCCCA; } \\
\text { R_CGCGTGAACAGCTTTTTGAGA }\end{array}$ & $\begin{array}{c}\text { AP2/ERF and B3 } \\
\text { domain-containing TF } \\
\text { RAV1-like (XM_024016479.1) }\end{array}$ & RAV1 AT1G13260 & $2 \times 10^{-102}(66 \%)$ \\
\hline
\end{tabular}

\section{Conclusions}

Our study provides an integrated overview of the early and later responses of $Q$. suber roots to a salt stress episode. The genes previously reported as over-represented in abiotic and biotic stress were investigated and validated in this study for different time points and ascribed to different putative functions. Data suggest that $Q$. suber response to a high dose of $\mathrm{NaCl}$ depends on the extent of the salinity exposure ( $8 \mathrm{~h}$ or 6 days). In an early stage (8 h), Q. suber upregulate genes (QsRAV1, QsLTI30, QsCZF1, and QsFAD7) that can provide some salt tolerance and adaptation, with particular emphasis to genes related with the synthesis of dehydrins and/or membrane protection, which might be associated with the observed low levels of lipid peroxidation. Additionally, the antioxidant enzymes, SOD and CAT, also contribute to this early salt stress response, possibly acting in the detoxification of superoxide. Then, with the extent of stress (6 days) and appearance of signs of oxidative damages (increase of lipid peroxidation), besides the upregulation of QsLTI30, other genes related to oxidative stress/antioxidant defence system (QsCSD1 and QsAPX2) were activated, together with a boost in the antioxidant enzyme activities (e.g., SOD and APX), TAA, and phenols. In conclusion, Q. suber roots' early responses to high salt stress point to initial mechanisms of membrane protection, dehydrins synthesis and/or transcription factors regulating protective genes, together with antioxidant enzymes activation. However, with the extent of the salinity, the latter responses include complementary antioxidant protective strategies to deal with the increase of oxidative stress. These data confirm the high tolerance of this species to salinity and reveal the strategies activated by roots to cope with this stress condition. Beside the analysed parameters, other important stress biomarkers such as osmolytes (e.g., proline or glycine-betain),nutrient contents, and reactive oxygen species (e.g., $\mathrm{H}_{2} \mathrm{O}_{2}$ ) deserve further studies to understand their role in $Q$. suber response and tolerance to salt stress. 


\begin{abstract}
Author Contributions: Conceptualization, C.S., J.M.P.F.d.O., M.C.D. and M.O.; validation, J.M.P.F.d.O. and M.C.D.; formal analysis, J.M.P.F.d.O., M.A. and M.C.D.; investigation, J.M.P.F.d.O., P.M.B., M.O. and M.C.D.; writing—original draft preparation, J.M.P.F.d.O., M.A. and M.C.D.; writing-review and editing, C.S. and M.O. All authors have read and agreed to the published version of the manuscript.

Funding: This work was supported by FEDER through the Operational Competitiveness ProgramCOMPETE—within the scope of project "PTDC/AGRGPL/118505/2010 "An integrated approach to identify stress-related regulatory genes in cork oak (SuberStress)", and from PT national funds (FCT/MCTES, Fundação para a Ciência e a Tecnologia and Ministério da Ciência, Tecnologia e Ensino Superior) within the scope of the projects UIDB/50006/2020 and UID/BIA/04004/2020 (CEF UI0183). J.M.P. Ferreira de Oliveira (grant number SFRH/BPD/74868/2010) and M.C. Dias (grant number SFRH/BPD/100865/2014) thank FCT (Fundação para a Ciência e Tecnologia) for funding through program DL 57/2016-Norma transitória. PMRB and MMO thank the Research Unit “GREEN-IT Bioresources for Sustainability"-FCT refs. (UID/Multi/04551/2013 and UIDB/04551/2020). FCT also supported the doctoral fellowships of M. Araújo (SFRH/BD/116801/2016).
\end{abstract}

Institutional Review Board Statement: Not applicable.

Informed Consent Statement: Not applicable.

Acknowledgments: The authors thank G. Pinto and J. Amaral for their technical support.

Conflicts of Interest: The authors declare no conflict of interest.

\title{
References
}

1. Aragüés, R.; Urdanoz, V.; Çetin, M.; Kirda, C.; Daghari, H.; Ltifi, W.; Lahlou, M.; Douaik, A. Soil salinity related to physical soil characteristics and irrigation management in four Mediterranean irrigation districts. Agric. Water Manag. 2011, 98, 959-966. Available online: https:/ /linkinghub.elsevier.com/retrieve/pii/S0378377411000072 (accessed on 6 January 2022). [CrossRef]

2. Daliakopoulos, I.N.; Tsanis, I.K.; Koutroulis, A.; Kourgialas, N.N.; Varouchakis, A.E.; Karatzas, G.P.; Ritsema, C.J. The threat of soil salinity: A European scale review. Sci. Total Environ. 2016, 573, 727-739. [CrossRef] [PubMed]

3. Ma, Y.; Dias, M.C.; Freitas, H. Drought and Salinity Stress Responses and Microbe-Induced Tolerance in Plants. Front. Plant Sci. 2020, 11, 591911. [CrossRef] [PubMed]

4. Liu, Y.; Song, Q.; Li, D.; Yang, X.; Li, D. Multifunctional roles of plant dehydrins in response to environmental stresses. Front. Plant Sci. 2017, 8, 1018. Available online: http://journal.frontiersin.org/article/10.3389/fpls.2017.01018/full (accessed on 6 January 2022). [CrossRef] [PubMed]

5. Zhang, M.; Smith, J.A.C.; Harberd, N.P.; Jiang, C. The regulatory roles of ethylene and reactive oxygen species (ROS) in plant salt stress responses. Plant Mol. Biol. 2016, 91, 651-659. [CrossRef] [PubMed]

6. Guo, Q.; Liu, L.; Barkla, B.J. Membrane lipid remodeling in response to salinity. Int. J. Mol. Sci. 2019, 20, 4264. Available online: https:/ / www.mdpi.com/1422-0067/20/17/4264 (accessed on 6 January 2022). [CrossRef]

7. van Zelm, E.; Zhang, Y.; Testerink, C. Salt Tolerance Mechanisms of Plants. Annu. Rev. Plant Biol. 2020, 71, 403-433. [CrossRef] [PubMed]

8. Lu, Y.; Su, W.; Bao, Y.; Wang, S.; He, F.; Wang, D.; Yu, X.; Yin, W.; Liu, C.; Xia, X. Poplar PdPTP1 gene negatively regulates salt tolerance by affecting ion and ROS homeostasis in Populus. Int. J. Mol. Sci. 2020, 21, 1065. Available online: https: / / www.mdpi.com/1422-0067/21/3/1065 (accessed on 6 January 2022). [CrossRef]

9. Kimotho, R.N.; Baillo, E.H.; Zhang, Z. Transcription factors involved in abiotic stress responses in Maize (Zea mays L.) and their roles in enhanced productivity in the post genomics era. PeerJ 2019, 2019, e7211. Available online: https://peerj.com/articles/7211 (accessed on 6 January 2022). [CrossRef]

10. Gahlaut, V.; Jaiswal, V.; Kumar, A.; Gupta, P.K. Transcription factors involved in drought tolerance and their possible role in developing drought tolerant cultivars with emphasis on wheat (Triticum aestivum L.). Theor. Appl. Genet. 2016, 129, $2019-2042$. [CrossRef]

11. Rashid, M.; Guangyuan, H.; Guangxiao, Y.; Hussain, J.; Xu, Y. AP2/ERF Transcription Factor in Rice: Genome-Wide Canvas and Syntenic Relationships between Monocots and Eudicots. Evol. Bioinforma 2012, 8, 321-355. [CrossRef] [PubMed]

12. Yang, Y.; Al-Baidhani, H.H.J.; Harris, J.; Riboni, M.; Li, Y.; Mazonka, I.; Bazanova, N.; Chirkova, L.; Sarfraz Hussain, S.; Hrmova, M.; et al. DREB/CBF expression in wheat and barley using the stress-inducible promoters of HD-Zip I genes: Impact on plant development, stress tolerance and yield. Plant Biotechnol. J. 2020, 18, 829-844. [CrossRef] [PubMed]

13. Cui, Y.N.; Wang, F.Z.; Yang, C.H.; Yuan, J.Z.; Guo, H.; Zhang, J.L.; Wang, S.M.; Ma, Q. Transcriptomic profiling identifies candidate genes involved in the salt tolerance of the xerophyte Pugionium cornutum. Genes 2019, 10, 1039. Available online: https: / / www.mdpi.com/2073-4425/10/12/1039 (accessed on 6 January 2022). [CrossRef] [PubMed]

14. Sun, J.; Jiang, H.; Xu, Y.; Li, H.; Wu, X.; Xie, Q.; Li, C. The CCCH-type zinc finger proteins AtSZF1 and AtSZF2 regulate salt stress responses in Arabidopsis. Plant Cell Physiol. 2007, 48, 1148-1158. [CrossRef] 
15. Miller, G.; Suzuki, N.; Ciftci-Yilmaz, S.; Mittler, R. Reactive oxygen species homeostasis and signalling during drought and salinity stresses. Plant Cell Environ. 2010, 33, 453-467. [CrossRef]

16. Pereira-Leal, J.B.; Abreu, I.A.; Alabaça, C.S.; Almeida, M.H.; Almeida, P.; Almeida, T.; Amorim, M.I.; Araújo, S.; Azevedo, H.; Badia, A.; et al. A comprehensive assessment of the transcriptome of Cork oak (Quercus suber) through EST sequencing. BMC Genom. 2014, 15, 371. Available online: http:/ / www.fagaceae (accessed on 6 January 2022). [CrossRef]

17. Kim, H.N.; Jin, H.Y.; Kwak, M.J.; Khaine, I.; You, H.N.; Lee, T.Y.; Ahn, T.H.; Woo, S.Y. Why does Quercus suber species decline in Mediterranean areas? J. Asia-Pac. Biodivers. 2017, 10, 337-341. [CrossRef]

18. Faivre Rampant, P.; Lesur, I.; Boussardon, C.; Bitton, F.; Martin-Magniette, M.L.; Bodénès, C.; Le Provost, G.; Bergès, H.; Fluch, S.; Kremer, A.; et al. Analysis of BAC end sequences in oak, a keystone forest tree species, providing insight into the composition of its genome. BMC Genom. 2011, 12, 292. [CrossRef]

19. Miguel, A.; de Vega-Bartol, J.; Marum, L.; Chaves, I.; Santo, T.; Leitão, J.; Varela, M.C.; Miguel, C.M. Characterization of the cork oak transcriptome dynamics during acorn development. BMC Plant Biol. 2015, 15, 158. [CrossRef]

20. Cha-um, S.; Kirdmanee, C. Effects of water stress induced by sodium chloride and mannitol on proline accumulation, photosynthetic abilities and growth characters of eucalyptus (Eucalyptus camaldulensis Dehnh.). New For. 2010, 40, 349-360. [CrossRef]

21. Hernández, J.A. Salinity tolerance in plants: Trends and perspectives. Int. J. Mol. Sci. 2019, 20, 2408. [CrossRef]

22. Sedas, A.; Gonzalez, Y.; Winter, K.; Lopez, O.R. Seedling responses to salinity of 26 Neotropical tree species. AoB Plants 2019, 11, plz062. [CrossRef] [PubMed]

23. Wu, G.; Zhou, Z.; Chen, P.; Tang, X.; Shao, H.; Wang, H. Comparative ecophysiological study of salt stress for wild and cultivated soybean species from the yellow river delta, China. Sci. World J. 2014, 2014, 651745. [CrossRef] [PubMed]

24. Hasanuzzaman, M.; Nahar, K.; Rahman, A.; Anee, T.I.; Alam, M.U.; Bhuiyan, T.F.; Oku, H.; Fujita, M. Approaches to enhance salt stress tolerance in wheat. In Wheat Improvement, Management and Utilization; Wanyera, R., Owuoche, J., Eds.; IntechOpen: London, UK, 2017. [CrossRef]

25. Rahman, A.; Nahar, K.; Mahmud, J.A.; Hasanuzzaman, M.; Hossain, M.S.; Fujita, M. Salt stress tolerance in rice: Emerging role of exogenous phytoprotectants. In Advances in International Rice Research; Jinquan, L., Ed.; IntechOpen: London, UK, 2017. [CrossRef]

26. Ferreira de Oliveira, J.M.P.; Santos, C.; Araújo, M.; Oliveira, M.M.; Dias, M.C. High-salinity activates photoprotective mechanisms in Quercus suber via accumulation of carbohydrates and involvement of non-enzymatic and enzymatic antioxidant pathways. New For. 2021. [CrossRef]

27. Eriksson, S.K.; Kutzer, M.; Procek, J.; Gröbner, G.; Harryson, P. Tunable membrane binding of the intrinsically disordered dehydrin Lti30, a cold-induced plant stress protein. Plant Cell 2011, 23, 2391-2404. [CrossRef] [PubMed]

28. Puhakainen, T.; Hess, M.W.; Mäkelä, P.; Svensson, J.; Heino, P.; Palva, E.T. Overexpression of multiple dehydrin genes enhances tolerance to freezing stress in Arabidopsis. Plant Mol. Biol. 2004, 54, 743-753. [CrossRef] [PubMed]

29. Shi, H.; Chen, Y.; Qian, Y.; Chan, Z. Low Temperature-Induced 30 (LTI30) positively regulates drought stress resistance in Arabidopsis: Effect on abscisic acid sensitivity and hydrogen peroxide accumulation. Front. Plant Sci. 2015, 6, 893. [CrossRef]

30. Nishiuchi, T.; Hamada, T.; Kodama, H.; Iba, K. Wounding changes the spatial expression pattern of the Arabidopsis plastid $\omega-3$ fatty acid desaturase gene (FAD7) through different signal transduction pathways. Plant Cell 1997, 9, 1701-1712. [CrossRef]

31. Teixeira, M.C.; Carvalho, I.S.; Brodelius, M. w-3 Fatty acid desaturase genes isolated from purslane (Portulaca oleracea L.): Expression in different tissues and response to cold and wound stress. J. Agric. Food Chem. 2010, 58, 1870-1877. [CrossRef]

32. Feng, J.; Dong, Y.; Liu, W.; He, Q.; Daud, M.K.; Chen, J.; Zhu, S. Genome-wide identification of membrane-bound fatty acid desaturase genes in Gossypium hirsutum and their expressions during abiotic stress. Sci. Rep. 2017, 7, 45711. [CrossRef]

33. Wickramanayake, J.S.; Goss, J.A.; Zou, M.; Goggin, F.L. Loss of Function of Fatty Acid Desaturase 7 in Tomato Enhances Photosynthetic Carbon Fixation Efficiency. Front. Plant Sci. 2020, 11, 932. [CrossRef] [PubMed]

34. Park, S.; Lee, C.M.; Doherty, C.J.; Gilmour, S.J.; Kim, Y.; Thomashow, M.F. Regulation of the Arabidopsis CBF regulon by a complex low-temperature regulatory network. Plant J. 2015, 82, 193-207. [CrossRef] [PubMed]

35. Magalhães, A.P.; Verde, N.; Reis, F.; Martins, I.; Costa, D.; Lino-Neto, T.; Castro, P.H.; Tavares, R.M.; Azevedo, H. RNA-Seq and gene network analysis uncover activation of an ABA-dependent signalosome during the cork oak root response to drought. Front. Plant Sci. 2016, 6, 1195. Available online: http://journal.frontiersin.org/Article/10.3389/fpls.2015.01195/abstract (accessed on 6 January 2022). [CrossRef] [PubMed]

36. Min, Z.; Yanming, F.; Yonghua, J.; Zeping, J.; Lei, W. Effects of salt stress on ion content, antioxidant enzymes and protein profile in different tissues of Broussonetia papyrifera. S. Afr. J. Bot. 2013, 85, 1-9. [CrossRef]

37. Mittova, V.; Guy, M.; Tal, M.; Volokita, M. Salinity up-regulates the antioxidative system in root mitochondria and peroxisomes of the wild salt-tolerant tomato species Lycopersicon pennellii. J. Exp. Bot. 2004, 55, 1105-1113. [CrossRef]

38. Kim, S.Y.; Lim, J.-H.; Park, M.R.; Kim, Y.J.; Park, T.I.; Seo, Y.W.; Choi, K.G.; Yun, S.J. Enhanced antioxidant enzymes are associated with reduced hydrogen peroxide in barley roots under saline stress. J. Biol. Mol. Biol. 2005, 38, 218-224. [CrossRef]

39. Sarri, E.; Termentzi, A.; Abraham, E.M.; Papadopoulos, G.K.; Baira, E.; Machera, K.; Loukas, V.; Komaitis, F.; Tani, E. Salinity stress alters the secondary metabolic profile of M. sativa, M. arborea and their hybrid (Alborea). Int. J. Mol. Sci. 2021, $22,4882$. [CrossRef]

40. Petridis, A.; Therios, I.; Samouris, G.; Tananaki, C. Salinity-induced changes in phenolic compounds in leaves and roots of four olive cultivars (Olea europaea L.) and their relationship to antioxidant activity. Env. Exp. Bot. 2012, 79, 37-43. [CrossRef] 
41. Re, R.; Pellegrini, N.; Proteggente, A.; Pannala, A.; Yang, M.; Rice-Evans, C. Antioxidant activity applying an improved ABTS radical cation decolorization assay. Free Radic. Biol. Med. 1999, 26, 1231-1237. Available online: https: / /linkinghub.elsevier.com/ retrieve/pii/S0891584998003153 (accessed on 6 January 2022). [CrossRef]

42. Hodges, D.M.; DeLong, J.M.; Forney, C.F.; Prange, R.K. Improving the thiobarbituric acid-reactive-substances assay for estimating lipid peroxidation in plant tissues containing anthocyanin and other interfering compounds. Planta 1999, 207, 604-611. [CrossRef]

43. Wan, C.Y.; Wilkins, T.A. A modified hot borate method significantly enhances the yield of high-quality RNA from cotton (Gossypium hirsutum L.). Anal. Biochem. 1994, 223, 7-12. Available online: https://linkinghub.elsevier.com/retrieve/pii/S0003269 784715387 (accessed on 6 January 2022). [CrossRef] [PubMed]

44. Pfaffl, M.W. A new mathematical model for relative quantification in real-time RT-PCR. Nucleic. Acids Res. 2001, 29, e45. [CrossRef] [PubMed]

45. Rozen, S.; Skaletsky, H. Primer3 on the WWW for general users and for biologist programmers. In Methods in Molecular Biology Clifton, N.J., Ed.; Humana Press: Totova, NJ, USA, 2000; pp. 365-386. [CrossRef]

46. Agarwal, S.; Sairam, R.; Srivastava, G.; Meena, R. Changes in antioxidant enzymes activity and oxidative stress by abscisic acid and salicylic acid in wheat genotypes. Biol. Plant 2005, 49, 541-550. [CrossRef]

47. Nakano, Y.; Asada, K. Hydrogen peroxide is scavenged by ascorbate specific peroxidase in spinach chloroplasts. Plant Cell Physiol. 1981, 22, 867-880. [CrossRef]

48. Beers, R.; Sizer, I. A spectrophotometric method for measuring the breakdown of hydrogen peroxide by catalase. J. Biol. Chem. 1952, 195, 133-140. [CrossRef] 